\title{
Effects of the use of Documentary Videos in Teaching Setting-out in Nigerian Secondary Schools
}

\author{
M. A. Auta \& M. Giwa \\ Department of Technology and Vocational Education, Nnamdi Azikiwe University, Awka-Nigeria \\ Department of Building Technology, Federal College of Education (Technical), Asaba-Nigeria \\ muhammadauta@gmail.com,ma.auta@unizik.edu.ng
}

\begin{abstract}
The purpose of the study was to determine the effect of the use of documentary videos in teaching setting-out in Nigerian secondary schools. One research question and one hypothesis guided the study. The study adopted Quasi-experimental research design. The population for the study was 16 ST 1 students from Government Technical Training School, Jalingo offering Building Construction subject. There was no sampling. The instrument for data collection was Setting-out Test (ST) developed by the researcher. The instrument was validated by three experts. Test re-test was used to establish the reliability of the instrument and a reliability coefficient of 0.83 and 0.87 was obtained for the traditional and documentary video teaching methods respectively. The ST 1 students were arranged in intact groups, A and B; treatment was given to the two groups. Group a students were taught using the traditional method while Group B students were taught using the documentary video. A Pre-Test and Post-test was administered on the two groups under examination condition. The data obtained were analyzed using mean, standard deviation for research question and analysis of covariance (ANCOVA) for the hypothesis. Findings from the study indicated that students taught Setting-out with documentary videos performed better than those taught with the traditional teaching method; and there was a significant difference in the performance of students taught Setting-out with documentary video and those taught with traditional teaching method. Based on the findings some recommendations were made.
\end{abstract}

Keywords: Effects, Documentary Video, Teaching, Building, Construction.

\section{Introduction}

The world is now regarded as a global village. This is premised on the fact that, information availability is now at the fingertips of the people. The present era of internet and other multi-media devices presents unlimited avenue for both students and teachers around the world to access diverse information instantaneously. As a result of this evolution, the present generation is often regarded as "e-generation". Consequently, visual culture is now becoming a tool in the hand of the students; they utilize such tools not just for the purpose of education, but for playing and other engagements. It is therefore, an integral part of their upbringing. In the last few decades, the number of television viewing by both adults and the children have being on the rise (Gunter, 2010). This phenomenal increase in the utilization of these tools can be leveraged in the teaching and learning processes. Social media, such as twitter, facebook, instagram, wattsapp YouTube among others can be used for such purposes. However, these tools require internet services to function which may not be readily available particularly in the rural areas. Documentary video can play that noble role since it can be played off line. Documentary video is an aspect of audio-visual devices that can be used both on and offline for the purpose of instructions (Duschl \& Grandy, 2013).

This medium can provide a rich material for effective teaching and learning. Cakmakci and Yalaki (2012) had earlier noted that, documentary video have the potentials to effectively communicate complex information to the learners particularly when utilized in an innovative way with strong regards to their needs. For instance, when preparing a lesson for secondary school students, a little video clip at the beginning of the lesson may have the potential to add spices to the lesson. When it is utilized throughout the duration of the class, it can lead to meaningful teaching/learning. Building construction is one of the technology subjects taught in senior secondary schools. It is concerned with imparting in the students both the theory and practical skills needed to undertake simple building construction work. It also prepares the students for further studies in the field of technology either in the polytechnic, universities or other institutions of higher learning. According to the Nigeria Education Research and Development Council (NERDC) (2012), building construction subject as taught in secondary school is geared towards equipping students with skills in processes, materials, tools and equipment used in building construction and to inculcate in them safe working habits in building construction. 
This will lay a solid foundation for technological development and for the students to further their studies in, building construction and other engineering programmes. Setting out is one of the tasks taught in building construction at secondary school. Setting out is a process of interpreting a building design from the paper to its actual position on the ground (Obande, 2004). This task can be carried out using the builder square method, 3, 4, 5 method, or through effective utilization of a leveling instrument such as Theodolite (Emitt \& Gorse, 2005). The choice of which method to adopt is determined by the nature of the job as well as the individual expertise of the building worker (Shetty, 2009). This therefore, requires high level of expertise on the part of the building worker. Presently, it appears that most of the building construction teachers in the secondary schools utilized the traditional teaching method in teaching difficult concepts in building construction subject, including setting-out. However, Building construction just like all other technology and vocational subjects by their nature, are practically oriented.

Therefore when traditional method of teaching is applied, it places the students in passive rather than active, participants in the learning process. This is evident in the fact that in 2018, most of the students examined by the West African Examination Council (WAEC) in Building Construction could not demonstrate the process and procedures of setting-out a simple rectangular building as required of them in the examination (West African Examination Council (WAEC), 2018; Okoye \& Auta, 2020). This apparent failure can be attributed to many factors including the method used in the teaching and learning of the subject. Though, the efficacy of the use of documentary video has been tested in other studies (Isiaka, 2007; Ozder, 2014; Kupuchu, Cakmakci \& Aydogdu, 2015; Adanali, 2018), there is no evidence that it was carried out on Setting-out. Hence, the need to test the application of documentary videos in teaching and learning of setting-out in order to determine if there will be significant improvement in the performance of the students.

Research Questions: The study answered the following research question:

- What are the mean performance scores of students taught setting-out using traditional and the documentary video teaching methods?

Hypothesis: The null hypothesis below was tested at 0.10 level of significance;

- There is no significant difference in the performance of students taught with traditional and documentary video teaching methods.

\section{Method}

The study adopted Quasi-experimental research design of non-equivalent experimental and control groups. Creswell (2014) noted that, in this type of design, the researcher manipulates the independent variable in order to establish its effect on the criterion variable as shown below:

\begin{tabular}{lll}
\hline Pretest & Treatment & Posttest \\
\hline 01 & $\mathrm{X} 1$ & 02 \\
03 & $\mathrm{X} 2$ & 04 \\
\hline
\end{tabular}

*01, 03: Pretest on Setting-out

*02, 04: Posttest on Setting-out

*X1: Traditional Teaching method

*X2: Documentary video Teaching method

Therefore, in this study, the documentary video was the variable manipulated. The population for the study is 16 ST 1 students from Government Technical Training School, Jalingo offering Building Construction subject. The choice of ST 1 is based on the fact that they have not been taught with any of the two methods. There was no sampling; therefore, the entire population was used for the study. The instrument for data collection was Setting-out Test (ST) developed by the researcher based on the NERDC curriculum for building construction. The instrument was validated by three experts two from the department of technology education, Modibbo Adama university of Technology, Yola and one from Government Technical College (GTC), Gumau. Their suggestions were used to improve the instrument. Test re-test was used to establish the reliability of the instrument after administering a pilot test on 8 ST 1 students shared into two groups of 4 each in GTC, Yola at 
two different times in an interval of two weeks. One group was taught setting-out using the traditional method while the other group was taught using the video documentary method.

The results obtained from the first and second tests were analyzed using Pearson product moment correlation coefficient and a reliability coefficient of 0.83 and 0.87 was obtained for the traditional and documentary, video teaching methods respectively. During the experiment, the researchers prepared a lesson plan on Setting-out in accordance with the NERDC curriculum for Building construction. The ST 1 students were arranged in intact groups, A and B; treatment was given to the two groups. Group a students were taught using the traditional method while Group B students were taught using the documentary video. A PreTest and Post-test was administered on the two groups under examination condition. The data obtained were analyzed using mean, standard deviation for research question and Analysis of Covariance (ANCOVA) for the hypothesis.

\section{Results}

Research Question 1: What are the mean performance scores of students taught setting-out using traditional and the documentary video teaching methods?

Table 1: Performance Mean Scores and Standard Deviation of Students Taught Setting-Out with Traditional Method and Documentary Video Teaching Methods

\begin{tabular}{llllllll}
\hline Group & & N & $\begin{array}{l}\text { Pre-Test } \\
\text { Mean }\end{array}$ & SD & $\begin{array}{l}\text { Post-Test } \\
\text { Mean }\end{array}$ & SD & Gain Score \\
\hline $\begin{array}{l}\text { Traditional } \\
\begin{array}{l}\text { Method } \\
\text { Documentary Video }\end{array}\end{array}$ & Teaching & 8 & 17.21 & 7.07 & 54.38 & 9.13 & 37.17 \\
\hline
\end{tabular}

The data in Table 1 revealed that the performance of students taught Setting-out with traditional teaching method had a pre-test mean score of 17.21 with a $S D=7.07$ and a post-test mean score of 54.38 with a $S D=$ 9.13. The data also indicated that, the performance of students taught Setting-out with documentary video method had a pre-test mean score of 15.98 with a $\mathrm{SD}=9.67$ and a post-test mean score of 72.88 with a $\mathrm{SD}=$ 12.02. Comparatively, the gain score of the students taught Setting-out using the documentary video method (56.90) is higher than those taught using the traditional teaching method (37.17). Therefore, it can be concluded that students taught Setting-out with documentary videos performed better than those taught with the traditional teaching method.

Hypothesis: There is no significant difference in the performance of students taught with traditional and documentary video teaching method.

Table 2: Analysis of Covariance of Students Taught with Traditional and Documentary Video Teaching Methods

\begin{tabular}{|c|c|c|c|c|c|c|}
\hline $\begin{array}{l}\text { Sources } \\
\text { Variance }\end{array}$ & DF & $\begin{array}{l}\text { Sum } \\
\text { Squares }\end{array}$ & $\begin{array}{l}\text { Means } \\
\text { Squares }\end{array}$ & F-Cal & F-Crit & Significance \\
\hline Between groups & 1 & 38,457 & 38,457 & & & \\
\hline Within groups & 14 & 2,001 & 166.75 & 253.61 & 3.10 & Significant \\
\hline Total & 15 & 40,458 & & & & \\
\hline
\end{tabular}

The data presented in Table 2 shows that the F-calculated value (253.61) is greater than the F-critical value (3.10) at 0.10 level of significance. The hypothesis was rejected, indicating that there was a significant difference in the performance of students taught Setting-out with documentary video and those taught with traditional teaching method.

Discussion of Findings: The study was set to establish how the use of documentary video can affect students' performance in Setting-out. Findings from the study indicated that students taught Setting-out with documentary videos performed better than those taught with the traditional teaching method. These findings are in agreement with Ozder (2014) who discovered that the results of students taught with the use of 
documentary video showed improvement in their understanding when compared with those taught using the traditional approach. This could be as a result as a result of the fact that the documentary video approach utilizes both the audio and visual means in the instructional processes. Isiaka (2007) had earlier opined that the use of documentary video is not only imperative, but it makes teaching and learning particularly of difficult concepts more meaningful. Findings from the study also indicated that there was a significant difference in the performance of students taught Setting-out with documentary video and those taught with traditional teaching method. This is in consistent with that of Kapuchu, Cakmakci and Aydogdu, (2015) who discovered that the difference in the results of students taught using documentary video and those taught using the traditional teaching method is statistically significant.

\section{Conclusion and Recommendations}

Based on the findings, it was concluded that the teaching and learning of Setting-out component of Building construction subject in Nigerian Secondary school can be more meaningful and concrete when documentary videos is deployed in the learning process instead of the traditional method of instruction. That will significantly enhance their job performance in the field of work as well as acquiring a certification that will give a true reflection of the level of knowledge and skills they acquired in the course of their studies.

Recommendations: The following recommendations are made:

- NERDC and all other curriculum development agencies should emphasize the use of audio-visual media as part of instructional materials in teaching Building construction subject.

- School administrators should ensure that audio-visual media is compulsorily used as part of the instructional materials in teaching Building construction subject.

- Technical Teachers should leverage on the use of audio-visual media such as documentary video in the teaching of building construction subject.

\section{References}

Adanali, R. (2018). Effect of digital documentary production through fieldwork in geography students' problem-solving skills. Journal of Education and Training Studies, 6(1), 113-123.

Cakmakci, G. \& Yalaki, Y. (2012). Promoting student teachers' ideas about nature of science through popular media. Norway: S-TEAM/NTNU

Creswell, J. W. (2014). Research design: qualitative, quantitative and mixed methods approaches (4th ed.). Thousand Oak, CA: Sage Publishers Inc

Duschl, R. A. \& Grandy, R. (2013). Two views about explicitly teaching nature of science. Science and Education, 22(9), 2289-2315.

Emitt, S. \& Gorse, C. (2005). Barry's introduction to construction of buildings. Oxford: Blackwell Publishing.

Gunter, B. (2010). Audience evolution pattern. Accessed at http://doi.org/10.1016/B978-1-84334-6364.50001-5

Isiaka, B. (2007). Effectiveness of video as an instructional medium in teaching rural children agricultural and environmental sciences. International Journal of Education and Development using Information and Communication Technology, 3(3), 104-114.

Kapuchu, M. S., Cakmakci, G. \& Aydogdu, C. (2015). The influence of documentary films on $8^{\text {th }}$ grade students' views about nature of science. Educational Sciences: Theory and Practice, 15(3), 797-808.

Nigerian Educational research and Development Council (NERDC). (2012). Building construction for SS1-3. Abuja: NERDC Press

Obande, M. O. (2004). Blocklaying and concreting. England: Longman Group.

Okoye, K. R. E. \& Auta, M. A. (2020). Development and validation of instrument for assessing student practical skills in building super-structure operations in Nigerian secondary schools. International Journal of Social Sciences \& Educational Studies, 7(2), 1-12.

Ozder, A. (2014). Documentaries as a tool to convey life into geography education. International Journal of Academic Research in Business and Social Sciences, 4(7), 203-212.

Shetty, M. S. (2009). Concrete technology: Theory and practice. New Delhi: S. Chand \& Company

West African Examination Council (WAEC). (2018). Chief examiners reports. Lagos: WAEC 